Research Article

\title{
One-Step Ultrafiltration Process for Separation and Purification of a Keratinolytic Protease Produced with Feather Meal
}

\author{
Juliana R. Machado, ${ }^{1}$ Emanuelle E. Severo, ${ }^{1}$ Janaina M. G. de Oliveira $\left(\mathbb{D},{ }^{1}\right.$ \\ Joana da C. Ores $\left(\mathbb{D},{ }^{1}\right.$ Adriano Brandelli, ${ }^{2}$ and Susana J. Kalil $\left({ }^{1}{ }^{1}\right.$ \\ ${ }^{1}$ Escola de Química e Alimentos, Universidade Federal do Rio Grande, P.O. Box 474, 96203900 Rio Grande, RS, Brazil \\ ${ }^{2}$ Laboratório de Bioquímica e Microbiologia Aplicada, Universidade Federal do Rio Grande do Sul, 91501-970 Porto Alegre, \\ RS, Brazil
}

Correspondence should be addressed to Susana J. Kalil; dqmsjk@furg.br

Received 14 February 2018; Accepted 30 April 2018; Published 28 June 2018

Academic Editor: Donald L. Feke

Copyright (c) 2018 Juliana R. Machado et al. This is an open access article distributed under the Creative Commons Attribution License, which permits unrestricted use, distribution, and reproduction in any medium, provided the original work is properly cited.

\begin{abstract}
A purification technique to obtain keratinolytic proteases produced by Bacillus sp. P45 in a medium containing chicken feather meal as substrate is presented. The experiments were carried out in a dead-end ultrafiltration unit, and the influence of the membrane cutoff, $\mathrm{pH}$ of enzymatic extract, and operating pressure on the purification of keratinase were studied. The one-step ultrafiltration process with the membrane molecular mass cutoff of $10 \mathrm{kDa}$ at $\mathrm{pH} 8.0$ and operating pressure of $0.147 \mathrm{MPa}$ showed an enzyme recovery of $87.8 \%$ and a 4.1 -fold purification factor. It is showed that ultrafiltration could be potentially used in the purification of keratinases.
\end{abstract}

\section{Introduction}

Brazil is a major producer of poultry meat globally, generating tons of organic waste such as viscera, feet, bones, feathers, and blood that are not exploited for human consumption. These organic by-products are mostly used to prepare animal feed or soil fertilizers though methods of incineration in the disposal of such waste are still applied in some locations [1]. Chicken feathers represent about $10 \%$ of the waste disposed of by the poultry industry. Feathers are essentially composed of keratin (about $90 \% \mathrm{w} / \mathrm{w}$ ), a protein of difficult degradation due to the presence of strong chemical bonds in the polypeptide chain as disulfide bridges, hydrogen, and hydrophobic interactions that hinder their rapid degradation in the environment [2-4].

The recovery of keratin poses a great challenge to the poultry industry. An alternative to recycle these keratinous materials is the bioconversion into products with higher added value by specific microorganisms producing keratinolytic proteases. These proteases, named keratinases, are often serine or metalloproteases capable of degrading keratinous wastes $[5,6]$. Alkaline keratinases are produced by several bacterial species, including Bacillus licheniformis [7-9], Kocuria rosea [10], Streptomyces sp. [11], and even fungi such as Aspergillus niger [12]. A keratinase-producing bacterium, Bacillus sp. P45, was isolated from the intestine of the Amazon basin fish Piaractus mesopotamicus [4]. Bacillus sp. P45 efficiently degraded feather keratin during submerged cultivations, producing extracellular keratinolytic enzymes.

This type of enzyme has gained biotechnological interest for use in the fertilizer, detergents, and cosmetic industries, and also for the potential use of keratinous residues to produce biohydrogen and biogas $[1,3,13]$. Furthermore, keratinolytic proteases can be applied to obtain animal feed rich in amino acids. The enzymatic hydrolysis preserves essential amino acids such as methionine, lysine, and tryptophan and avoids the formation of nonnutritive amino acids such as lanthionine and lysinoalanine [14]. New applications have also been developed 
such as prion degradation for prevention of mad cow disease [3], biodegradable plastic manufacturing, and keratin peptide production $[14,15]$.

The feasibility of an industrial application of keratinases resides initially in obtaining the enzyme from a viable source, such as poultry feathers, and its purification using a simple protocol. Several techniques have been studied to purify microbial keratinases, including ammonium sulfate precipitation, solvent precipitation, ultrafiltration, ion exchange chromatography, gel filtration chromatography, hydrophobic interaction chromatography, and hydroxyapatite chromatography $[5,7-9,11,16]$. However, those studies employ purification processes with sequences of different techniques in order to obtain highly purified enzyme preparations needed to characterize the enzyme. In those protocols, the membrane separation has been applied only as a concentration step. For industrial applications, high degrees of purity are often not required. Thus, it is necessary to study industrially applicable techniques to purify microbial keratinases, reducing the costs of this process. In addition to scale-up problems, which limit protein production levels, the traditional techniques such as chromatography require complex instrumentation support to run efficiently and yield low throughput of product at an extremely high cost. Hence, a separation technique that can provide high productivity and purity at the same time at low process cost would certainly be beneficial to the biotechnology industry [17].

Ultrafiltration has been widely used for protein concentration and separation because of the lower complexity compared to the previously mentioned purification techniques [18]. The major advantage of the ultrafiltration processes over a conventional bioseparation processes is the high product throughput. However, in spite of widespread use of ultrafiltration in processes such as diafiltration and concentration, the potential for its use in protein fractionation has not been exploited in the biotechnology industry [17]. Nevertheless, there are studies that show that ultrafiltration can be applied to purification of enzymes, obtaining high yields and product purity at the same time [19-21].

This study provides a potential one-step purification process for obtaining a microbial keratinase. Furthermore, this process adds value to the most problematic by-product of the poultry industry. In the present research, the use of an industrially applicable technique for the purification of the keratinase obtained from Bacillus sp. P45 using feathers was studied. The enzyme was concentrated and purified by ultrafiltration. This approach allows obtaining a purified keratinase in a single step.

\section{Materials and Methods}

2.1. Microorganism and Inoculum Preparation. Bacillus sp. P45 (GenBank accession number AY962474) was maintained at $4^{\circ} \mathrm{C}$ on brain heart infusion (BHI) agar plates. For inoculum preparation, Bacillus sp. $\mathrm{P} 45$ was inoculated on BHI plates and incubated at $30^{\circ} \mathrm{C}$ for $24 \mathrm{~h}$. The cultures were gently scraped from the agar surface, added to a sterile $\mathrm{NaCl}$ solution $(8.5 \mathrm{~g} / \mathrm{L})$, and mixed until a homogeneous suspension with an optical density of 0.5 at $600 \mathrm{~nm}$ was obtained [22].
TABle 1: Experimental design $2^{3}$ in coded levels (real values).

\begin{tabular}{lccc}
\hline Trial & MWCO $(\mathrm{kDa})$ & $\mathrm{pH}$ & Pressure $(\mathrm{MPa})$ \\
\hline 1 & $-1(10)$ & $-1(7.0)$ & $-1(0.147)$ \\
2 & $+1(30)$ & $-1(7.0)$ & $-1(0.147)$ \\
3 & $-1(10)$ & $+1(8.0)$ & $-1(0.147)$ \\
4 & $+1(30)$ & $+1(8.0)$ & $-1(0.147)$ \\
5 & $-1(10)$ & $-1(7.0)$ & $+1(0.245)$ \\
6 & $+1(30)$ & $-1(7.0)$ & $+1(0.245)$ \\
7 & $-1(10)$ & $+1(8.0)$ & $+1(0.245)$ \\
8 & $+1(30)$ & $+1(8.0)$ & $+1(0.245)$ \\
\hline
\end{tabular}

MWCO: molecular weight cutoff.

2.2. Submerged Cultivation. The enzyme was produced by submerged cultivation as described by Daroit et al. [22] using the culture medium composed of $(\mathrm{g} / \mathrm{L})$ feather meal (50) and $\mathrm{NH}_{4} \mathrm{Cl}(5.25)$ prepared in a mineral medium $(\mathrm{NaCl}(0.5)$, $\mathrm{K}_{2} \mathrm{HPO}_{4}(0.3)$, and $\mathrm{KH}_{2} \mathrm{PO}_{4}(0.4)$ ). In Erlenmeyer flasks $(250 \mathrm{~mL})$ containing $50 \mathrm{~mL}$ of medium, the initial $\mathrm{pH}$ was adjusted to 7.0 before sterilization by autoclaving at $121^{\circ} \mathrm{C}$ for $15 \mathrm{~min}$. Cultures were initiated with $1 \%(\mathrm{v} / \mathrm{v})$ inoculum. The growing conditions were $30^{\circ} \mathrm{C}$ and $125 \mathrm{rpm}$ for $48 \mathrm{~h}$. At the end of the cultivation, the supernatant was separated by centrifugation $(5.000 \times \mathrm{g}$ for $20 \mathrm{~min})$, obtaining the crude enzyme extract.

2.3. Ultrafiltration (UF). Experiments were conducted in a dead-end ultrafiltration unit with a working volume of $160 \mathrm{~mL}$ stirred by a magnetic bar suspended down to $5 \mathrm{~mm}$ of the membrane. The module was equipped with a regenerated cellulose membrane (Millipore) having a total filtering area of $19.63 \mathrm{~cm}^{2}$. A new membrane was used for each experiment, and two different sizes were used with molecular weight cutoff of $10 \mathrm{kDa}$ and $30 \mathrm{kDa}$. The system was pressurized with compressed nitrogen, and the temperature was kept at $15^{\circ} \mathrm{C}$ to avoid enzyme denaturation. Prior to the ultrafiltration process with crude enzyme extract, a flux of water was passed through the membrane. A volume of $40 \mathrm{~mL}$ of crude enzyme extract was added, and the process was stopped when the volumetric concentration factor reached the value of 4 [21]. The enzyme activity and the protein content of the feed (input crude extract), retentate, and permeate were assayed at the end of each experiment.

2.4. Concentration and Purification of Keratinase by Ultrafiltration. The influence of the operating pressure, the $\mathrm{pH}$ of the enzyme extract, and the molecular weight cutoff (MWCO) during the ultrafiltration process was studied by a $2^{3}$ experimental design, totaling eight experimental trials carried out in duplicate. The responses evaluated were enzyme recovery and purification factor. The statistical analysis of the experimental design was performed using analysis of variance (ANOVA) with a confidence level of $95 \%$. Statistica 5.0 software (StatSoft Inc., USA) was used for the regression and graphical analysis of the data obtained by the experimental design. Table 1 presents the matrix of experimental design.

The efficiency of the process of concentration and purification of the enzyme keratinase by ultrafiltration was 
evaluated through the enzyme recovery and purification factor. The enzyme recovery $(\% R)$ was obtained by the ratio between the total activity in the retentate and the total activity in the feed. The purification factor (PF) was calculated by dividing the specific activity of the enzyme in the retentate $(\mathrm{U} / \mathrm{mg})$ by the specific activity of the enzyme extract used in the feed $(\mathrm{U} / \mathrm{mg})$.

2.5. Enzyme Assay. Keratinase activity was monitored using the soluble substrate azocasein (Sigma, Saint Louis, USA) as described by Daroit et al. [4]. One unit (U) of protease activity was defined as the amount of enzyme that caused an increase of 0.1 absorbance unit at the defined assay conditions.

2.6. Total Protein Determination. Protein was determined by the method of Lowry et al. [23], using bovine serum albumin (BSA) as the standard.

\section{Results and Discussion}

3.1. Study of Flux with Variation of pH, Operating Pressure, and MWCO in the Ultrafiltration Process. During the trials, the flux behavior in the process of concentration and purification of keratinase was evaluated (Figures 1 and 2). In the ultrafiltration at $\mathrm{pH} 7.0$ (Figure 1), it is possible to observe that the flux variation of trial 2 was 76.4 to $25 \mathrm{~L} / \mathrm{m}^{2} \cdot \mathrm{h}$ with a reduction of $67.5 \%$ and an operating time of $0.6 \mathrm{~h}$. Trials 5 and 6 showed a flux reduction of 65.1 and $64.4 \%$, respectively. Trial $1(10 \mathrm{kDa}$ and $0.147 \mathrm{MPa})$ showed the smallest flux variation from 38.2 to $19.5 \mathrm{~L} / \mathrm{m}^{2} \cdot \mathrm{h}$ with a reduction of $48.9 \%$ and an operating time of $0.73 \mathrm{~h}$.

In Figure 2, the flux profiles at $\mathrm{pH} 8.0$ show that the membrane cutoff and the operating pressure affect the permeate flux more than the $\mathrm{pH}$-the change for $\mathrm{pH} 8.0$ in trials $3,4,7$, and 8 has no significant influence on the flux permeate, compared with the same conditions at $\mathrm{pH}$ 7.0. Trial $3(10 \mathrm{kDa}, 0.147 \mathrm{MPa}$, and $\mathrm{pH} 8.0)$ had the lowest percentage decrease of the flux with a value of $46.1 \%$ (39 to $21 \mathrm{~L} / \mathrm{m}^{2} \cdot \mathrm{h}$ ), almost the same as trial $1(48.9 \%)$, which is performed with the same MWCO and operating pressure but with $\mathrm{pH}$ 7.0.

When the effect of the membrane cutoff on the permeate flux was analyzed, it was observed that, with the $30 \mathrm{kDa}$ membrane, the reduction of the flux is larger than with the $10 \mathrm{kDa}$ membrane at low pressures $(0.147 \mathrm{MPa})$. This may be attributed to the fact that the extract contains peptides, amino acids, and other proteolytic enzymes with molecular mass below $30 \mathrm{kDa}$, which facilitates their initial transport through the membrane, thereby obtaining a higher initial flux of the process. However, due to the concentration polarization and fouling phenomena, the flow rate drops to values as low as those obtained with $10 \mathrm{kDa}$.

The flux reductions caused by the fouling and concentration polarization have long been recognized as major problems in the protein ultrafiltration. It could be seen that, at the beginning of the process, there is a rapid decline of the flux. After this initial period, there is a gradual decline of the

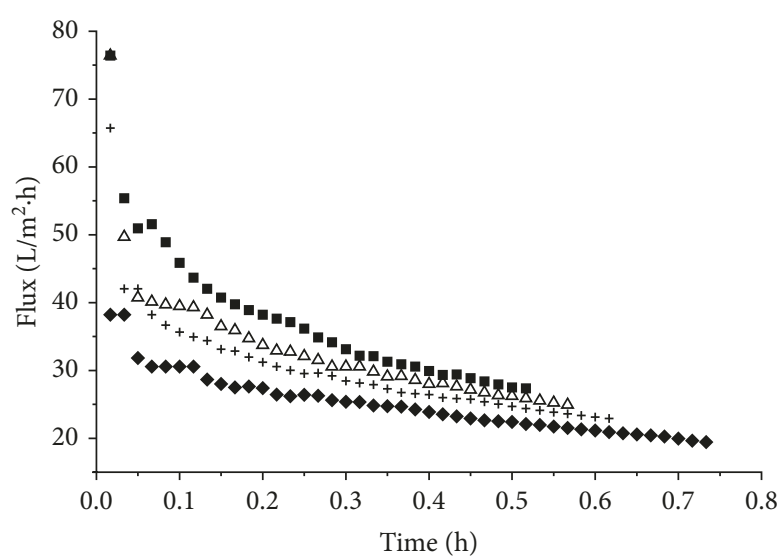

FIGURE 1: The flux permeate during the ultrafiltration process at $\mathrm{pH}$ 7.0: trial $1(\diamond): 10 \mathrm{kDa}$ and $0.147 \mathrm{MPa}$; trial $2(\Delta): 30 \mathrm{kDa}$ and $0.147 \mathrm{MPa}$; trial $5(+): 10 \mathrm{kDa}$ and $0.245 \mathrm{MPa}$; trial $6(\triangleleft): 30 \mathrm{kDa}$ and $0.245 \mathrm{MPa}$.

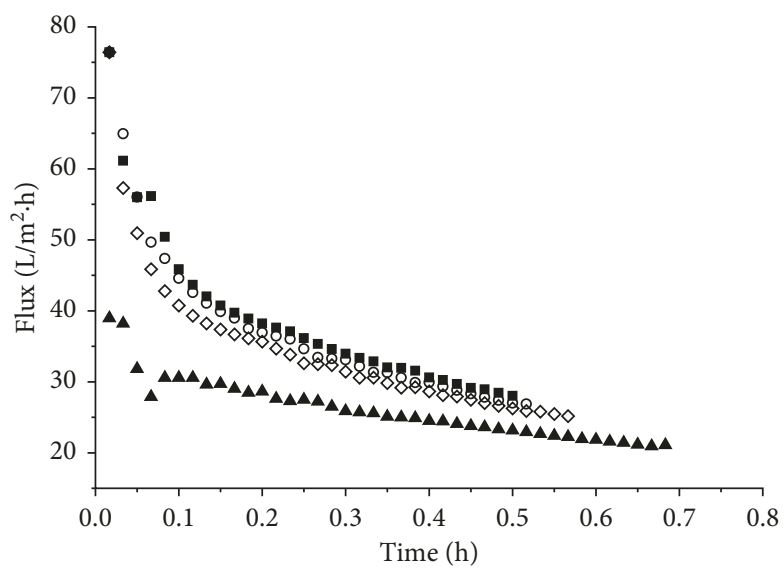

FIgURE 2: The flux permeate during the ultrafiltration process at $\mathrm{pH}$ 8.0: trial $3(\mathbf{\Delta}): 10 \mathrm{kDa}$ and $0.147 \mathrm{MPa}$; trial $4(\diamond): 30 \mathrm{kDa}$ and $0.147 \mathrm{MPa}$; trial $7(\mathrm{O}): 10 \mathrm{kDa}$ and $0.245 \mathrm{MPa}$; trial $8(\mathbf{\square}): 30 \mathrm{kDa}$ and $0.245 \mathrm{MPa}$.

flux that occurs due to the formation of incrustations of proteins into the membrane surface forming the effect of concentration polarization and the fouling phenomena. The proteins that are retained by the membrane can form a gel layer on the membrane surface, which acts as a second dynamic membrane, increasing protein retention. Other authors who used the ultrafiltration process for concentration and separation of proteins $[17,21,24]$ observed the same behavior. During the process of concentration and purification of a pretreated protease from the tuna spleen extract, a decline of 59\% was obtained in the flux [25], which is close to values obtained in this work.

However, at higher pressures $(0.245 \mathrm{MPa})$, the difference on the flux reduction between the $10 \mathrm{kDa}$ and $30 \mathrm{kDa}$ membranes is less pronounced. In fact, higher operating pressures provided higher initial flow rates in the process. This higher pressure may have decreased the effect of concentration polarization; thus, the process with the $10 \mathrm{kDa}$ membrane achieved initial fluxes close to the experiments with the $30 \mathrm{kDa}$ membrane. 
TABLe 2: Responses of $2^{3}$ experimental design.

\begin{tabular}{lcccccc}
\hline Trial & $\% R$ predicted & $\% R$ experimental & Relative standard (\%) & PF predicted & PF experimental & Relative standard (\%) \\
\hline 1 & 80.5 & 79.3 & -1.5 & 3.8 & 3.4 & -11.2 \\
2 & 40.1 & 41.3 & 3.0 & 2.3 & 2.1 & -11.4 \\
3 & 86.7 & 87.8 & 1.3 & 3.8 & 4.1 & 7.8 \\
4 & 46.2 & 44.6 & -3.7 & 2.3 & 3.9 & -23.2 \\
5 & 82.9 & 77.3 & -7.3 & 3.4 & 3.5 & -2.2 \\
6 & 62.7 & 62.2 & -0.9 & 3.7 & 3.7 & 1.7 \\
7 & 82.9 & 82.4 & -0.7 & 3.4 & 3.4 & 0.5 \\
8 & 68.9 & 69.4 & 0.7 & & 1.2 & \\
\hline
\end{tabular}

$n=2$; \%R: enzyme recovery; PF: purification factor.

TABLE 3: Analysis of variance for enzyme recovery and purification factor.

\begin{tabular}{|c|c|c|c|c|c|c|}
\hline & Factor & Sum of square & Degrees of freedom & Mean squares & $F_{\text {calculated }}$ & $F_{\text {tabulated }}$ \\
\hline \multirow{3}{*}{$\% R(R=0.99)$} & Regression & 4175.8 & 4 & 1043.9 & 300.8 & 3.4 \\
\hline & Residue & 38.2 & 11 & 3.5 & & \\
\hline & Total corrected & 4213.9 & 15 & & & \\
\hline \multirow{3}{*}{$\mathrm{PF}(R=0.84)$} & Regression & 5.3 & 3 & 1.8 & 9.00 & 3.5 \\
\hline & Residue & 2.2 & 12 & 0.2 & & \\
\hline & Total corrected & 7.5 & 15 & & & \\
\hline
\end{tabular}

3.2. Concentration and Purification of Keratinase by Ultrafiltration. Table 2 shows the values of the parameters evaluated during keratinase purification and the relative standard deviations with the predicted and experimental values obtained in the trials. The recovery of the enzyme keratinase was in the range of 41.3 to $87.8 \%$ and a purification factor between 1.9- and 4.1-fold. It was possible to verify that the increase of the membrane cutoff from 10 to $30 \mathrm{kDa}$ decreases the recovery of enzyme and consequently the purification factor. Trial 3, with a membrane cutoff of $10 \mathrm{kDa}, \mathrm{pH} 8.0$, and pressure of $0.147 \mathrm{MPa}$, provided the highest enzyme recovery $(87.8 \%)$ and purification factor (4.1-fold). The membrane cutoff, the operating pressure, and the interaction between these two variables had significant effect on the two responses, enzyme recovery and purification factor; the $\mathrm{pH}$, on the other hand, had a significant effect on the purification factor only. ANOVA was carried out using Fisher's statistical test (Table 3 ) for the validation of the empirical model obtained for the PF and recovery of the enzyme. Correlation coefficients $(R)$ of 0.99 and 0.84 were obtained for the $\% R$ and $P F$, respectively. In addition to this, the $F_{\text {calculated }}$ value was 3 times higher than the $F_{\text {tabulated }}$ value for the $\mathrm{PF}$ and 90 times higher for the $\% R$, showing that the model fitted the data satisfactorily and was considered predictive for both responses. Equations (1) and (2) represent empirical models codified for recovery $(\% R)$ and purification factor (FP), respectively.

$$
\begin{aligned}
\% R= & 68.11-13.62 * \mathrm{MWCO}+3.08 * \mathrm{pH} \\
& +4.735 * P+6.60 * \mathrm{MWCO} * P \\
\mathrm{PF}= & 3.31-0.42 * \mathrm{MWCO}+0.25 * P+0.3 * \mathrm{MWCO} * P,
\end{aligned}
$$

where $\% R$ is the enzyme recovery, $\mathrm{PF}$ is the purification factor, MWCO is the molecular mass cutoff, and $P$ is the operating pressure.
Figures 3 and 4 show the contour plots obtained from the empirical models for better understanding of the interaction of the variables $\mathrm{pH}$, pressure, and $\mathrm{MWCO}$ and to obtain the best conditions for keratinase concentration and purification.

Analyzing the interaction of $\mathrm{pH}$ and pressure on enzyme recovery, it is possible to verify that when a $10 \mathrm{kDa}$ membrane was employed with higher values of $\mathrm{pH}$ (between 7.5 and 8.0) and pressure between 0.196 and $0.147 \mathrm{MPa}$, the enzyme recovery increased (up to $80 \%$ ), as shown in Figure 3. When a $30 \mathrm{kDa}$ membrane was used, the effect of pressure on recovery values was even more pronounced. This is probably attributed to the formation of fouling that favors the retention of the enzyme.

With respect to the purification factor, the $\mathrm{pH}$ of the enzyme extract did not affect this response significantly, not generating the contour curve. The effect of $\mathrm{pH}$ is more related to the enzyme activity-keratinases usually have a great stability in neutral and alkaline $\mathrm{pH}[2,14]$. Only the MWCO and operating pressure had an influence on the purification factor (Figure 4). It was observed that higher purification factor values were obtained using lower MWCO values with operation pressures between 0.147 and $0.196 \mathrm{MPa}$.

Evaluating the influence of the MWCO, a negative effect was observed for both responses (recovery and purification factor). In other words, when the smallest MWCO is used $(10 \mathrm{kDa})$, the highest values of recovery and purification factor are obtained. An MWCO of $30 \mathrm{kDa}$ decreased the enzyme recovery by $27.2 \%$. This can be attributed to the molecular mass of the enzyme under study. According to Daroit et al. [26], the molecular mass of keratinase from Bacillus sp. P45 is approximately $26 \mathrm{kDa}$, and thus, higher MWCO favors the passage of the enzyme to permeate, decreasing the recovery of the enzyme.

Despite the enzyme having a molecular mass of $26 \mathrm{kDa}$, the $30 \mathrm{kDa}$ membrane was tested because it was expected that the concentration polarization and fouling phenomena could favor the retention of the enzyme due to formation of 


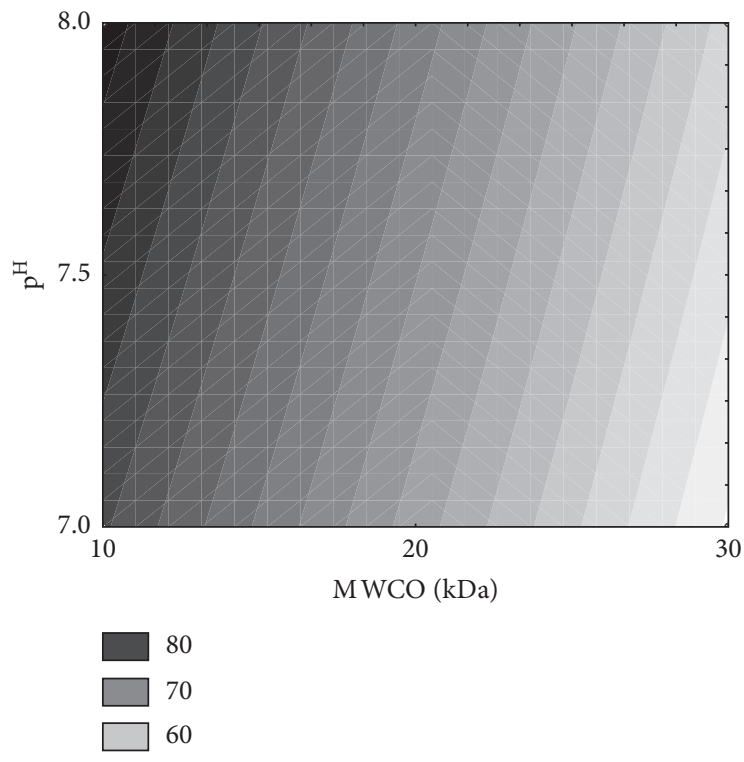

(a)

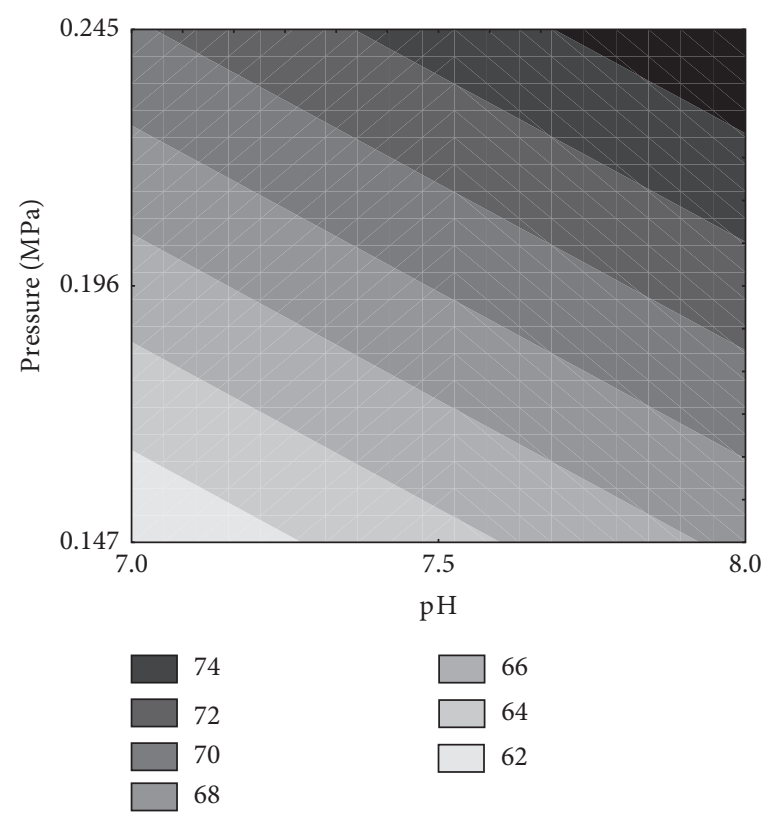

(b)

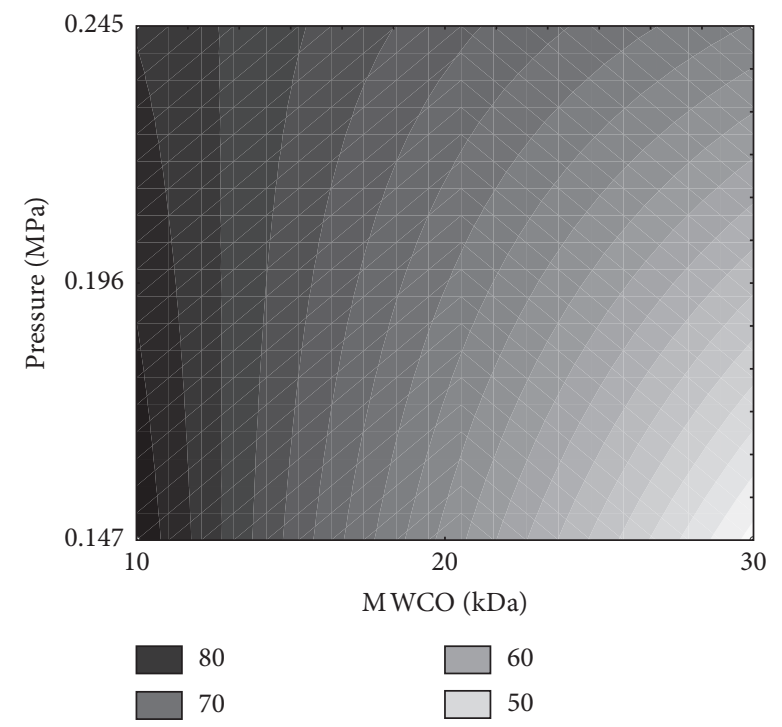

(c)

Figure 3: Contour curves for the recovery of enzyme as a function of (a) $\mathrm{pH}$ and MWCO, (b) $\mathrm{pH}$ and the operating pressure, and (c) MWCO and operating pressure.

the gel layer without major losses in the flux since it is a membrane with a larger pore diameter. Actually, a higher flow was observed, but the retention of the keratinase was much less efficient compared to the $10 \mathrm{kDa}$ membrane. Therefore, the enzyme permeated the membrane of $30 \mathrm{kDa}$ resulting in a smaller recovery and purification factor.

In relation to the pressure, it can be verified that lower pressures and MWCO provide values of higher purification factors. Furthermore, membranes of lower molecular mass cutoff with high values of $\mathrm{pH}$ and low operation pressures provide higher recovery values. Analyzing the flux behavior, at higher pressures $(0.245 \mathrm{MPa})$, the reduction of the flux was more pronounced in the best condition $(10 \mathrm{kDa}$ membrane and $\mathrm{pH}$ 8) compared with lower pressures $(0.147 \mathrm{MPa})$.

Ultrafiltration has been applied in the purification of keratinases only intended to concentrate the enzyme for the next purification step [7, 8, 27-29]. However, it is observed that the values found in the cited works are lower than those found in this study that use just one step. Radha and Gunasekaran [27] produced a keratinase by a recombinant Bacillus megaterium. During the purification process, the ultrafiltration step (MWCO of $10 \mathrm{kDa}$ ) achieved a purification factor of 2.3 -fold with a recovery of $73.5 \%$. Lin et al. [7] purified and characterized a keratinase isolated from a feather-degrading culture medium inoculated with Bacillus licheniformis PWD-1. 


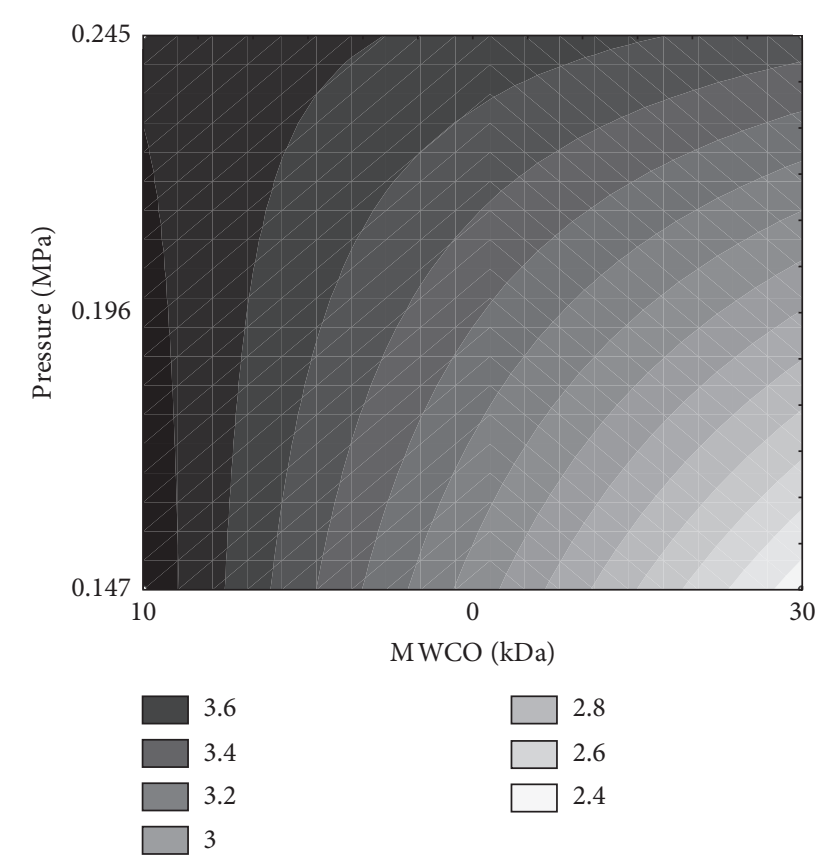

FIGURE 4: Contour curve for purification factor as a function of operating pressure and MWCO.

The ultrafiltration step (MWCO of $10 \mathrm{kDa}$ ) achieved a purification factor of 1.8 -fold and recovery of $69.3 \%$. In the study of Allpress et al. [28], the extracellular keratinase produced by Lysobacter NCIMB 9497 was purified for further characterization. In the ultrafiltration step (MWCO of $10 \mathrm{kDa}$ ), a purification factor of 2-fold was obtained.

Cheng et al. [8] and Suntornsuk et al. [29] also used a membrane MWCO of $10 \mathrm{kDa}$ for keratinase concentration. Cheng et al. [8] characterized the keratinase produced by Bacillus licheniformis PWD-1 produced with feather powder. Prior to the purification process, the enzyme was concentrated using a spiral cartridge concentrator with a MWCO membrane of $10 \mathrm{kDa}$. Suntornsuk et al. [29] isolated and determined the properties of a keratinase produced by a thermotolerant feather-degrading bacterial strain from Thai soil. For its purification, the enzyme was firstly concentrated by a $10 \mathrm{kDa}$ MWCO membrane.

In this study, an ultrafiltration process was developed in the purification of keratinase from Bacillus sp. P45 in a single step. A system with an operating pressure of $0.147 \mathrm{MPa}$, membrane MWCO of $10 \mathrm{kDa}$, and $\mathrm{pH}$ of 8.0 provided a 4 -fold purification factor without major recovery losses. Thus, it is possible to reduce the purification steps through an optimized ultrafiltration method for purification of this enzyme. The ease of operation and high efficiency makes the ultrafiltration process an interesting alternative in the purification of keratinases, which can be used in the degradation of resistant materials in effluents or even for applications in industry cleaning products like detergents. Besides, the enzyme has potential importance for production of protein hydrolysates [3].

\section{Conclusions}

The ultrafiltration system formed by the membrane with the molecular weight cutoff of $10 \mathrm{kDa}$, an operating pressure of $0.147 \mathrm{MPa}$, and a $\mathrm{pH}$ of 8.0 provided a recovery of $87.8 \%$ and 4.1-fold purification factor of the enzyme keratinase from Bacillus sp. P45. The ultrafiltration process is positioned as a potential alternative to be used for the industrial concentration and purification of keratinase from Bacillus sp. P45 in just one step. Furthermore, this process adds value to the most problematic by-product of the poultry industry, chicken feathers.

\section{Data Availability}

There are no supplementary data or materials for this article. However, the data used to support the findings of this study are available from the corresponding author upon request.

\section{Conflicts of Interest}

The authors declare that there are no conflicts of interest regarding the publication of this paper.

\section{Acknowledgments}

This work was supported by the Coordenação de Aperfeiçoamento de Pessoal de Nível Superior (CAPES) and the Conselho Nacional de Desenvolvimento Científico e Tecnológico $(\mathrm{CNPq})$ through research scholarships.

\section{References}

[1] A. Lasekan, F. Abu Bakar, and D. Hashim, "Potential of chicken by-products as sources of useful biological resources," Waste Management, vol. 33, no. 3, pp. 552-565, 2013.

[2] B. Bockle, B. Galunsky, and R. Muller, "Characterization of a keratinolytic serine proteinase from streptomyces pactum dsm 40530," Applied and Environmental Microbiology, vol. 61, no. 10, pp. 3705-3710, 1995.

[3] A. Brandelli, "Bacterial keratinases: useful enzymes for bioprocessing agroindustrial wastes and beyond," Food and Bioprocess Technology, vol. 1, no. 2, pp. 105-116, 2008.

[4] D. J. Daroit, A. P. F. Correa, and A. Brandelli, "Keratinolytic potential of a novel bacillus sp. P45 isolated from the Amazon basin fish Piaractus mesopotamicus," International Biodeterioration and Biodegradation, vol. 63, no. 3, pp. 358-363, 2009.

[5] C. Bernal, J. Cairo, and N. Coello, "Purification and characterization of a novel exocellular keratinase from kocuria rosea," Enzyme and Microbial Technology, vol. 38, no. 1-2, pp. 49-54, 2006.

[6] R. C. S. Thys and A. Brandelli, "Purification and properties of a keratinolytic metalloprotease from microbacterium sp.," Journal of Applied Microbiology, vol. 101, no. 6, pp. 1259-1268, 2006.

[7] X. A. Lin, C. G. Lee, E. S. Casale, and J. C. H. Shih, "Purification and characterization of a keratinase from a feather-degrading bacillus licheniformis strain," Applied and Environmental Microbiology, vol. 58, no. 10, pp. 3271-3275, 1992.

[8] S. W. Cheng, H. M. Hu, S. W. Shen, H. Takagi, M. Asano, and Y. C. Tsai, "Production and characterization of keratinase of 
a feather-degrading bacillus licheniformis pwd-1," Bioscience, Biotechnology, and Biochemistry, vol. 59, no. 12, pp. 22392243, 1995.

[9] E. Tiwary and R. Gupta, "Medium optimization for a novel $58 \mathrm{kDa}$ dimeric keratinase from bacillus licheniformis er-15: biochemical characterization and application in feather degradation and dehairing of hides," Bioresource Technology, vol. 101, no. 15, pp. 6103-6110, 2010.

[10] C. Bernal, L. Vidal, E. Valdivieso, and N. Coello, "Keratinolytic activity of kocuria rosea," World Journal of Microbiology and Biotechnology, vol. 19, no. 3, pp. 255-261, 2003.

[11] F. H. Xie, Y. P. Chao, X. Q. Yang et al., "Purification and characterization of four keratinases produced by streptomyces sp. strain 16 in native human foot skin medium," Bioresource Technology, vol. 101, no. 1, pp. 344-350, 2010.

[12] A. M. Farag and M. A. Hassan, "Purification, characterization and immobilization of a keratinase from Aspergillus oryzae," Enzyme and Microbial Technology, vol. 34, no. 2, pp. 85-93, 2004.

[13] G. Forgacs, S. Alinezhad, A. Mirabdollah, E. Feuk-Lagerstedt, and I. S. Horvath, "Biological treatment of chicken feather waste for improved biogas production," Journal of Environmental Sciences, vol. 23, no. 10, pp. 1747-1753, 2011.

[14] R. Gupta and P. Ramnani, "Microbial keratinases and their prospective applications: an overview," Applied Microbiology and Biotechnology, vol. 70, no. 1, pp. 21-33, 2006.

[15] A. Brandelli, D. J. Daroit, and A. Riffel, "Biochemical features of microbial keratinases and their production and applications," Applied Microbiology and Biotechnology, vol. 85, no. 6, pp. 1735-1750, 2010.

[16] J. M. Kuo, J. I. Yang, W. M. Chen et al., "Purification and characterization of a thermostable keratinase from meiothermus sp. 140," International Biodeterioration and Biodegradation, vol. 70, pp. 111-116, 2012.

[17] R. Ghosh and Z. F. Cui, "Protein purification by ultrafiltration with pre-treated membrane," Journal of Membrane Science, vol. 167, no. 1, pp. 47-53, 2000.

[18] R. van Reis and A. Zydney, "Bioprocess membrane technology," Journal of Membrane Science, vol. 297, no. 1-2, pp. 16-50, 2007.

[19] E. Nakkeeran, K. S. Venkatesh, R. Subramanian, and S. U. Kumar, "Purification of aspergillus carbonarius polygalacturonase using polymeric membranes," Journal of Chemical Technology and Biotechnology, vol. 83, no. 7, pp. 957-964, 2008.

[20] J. B. Wang, J. G. Liu, J. R. Lu, and Z. F. Cui, "Isolation and purification of superoxide dismutase from garlic using twostage ultrafiltration," Journal of Membrane Science, vol. 352, no. 1-2, pp. 231-238, 2010.

[21] S. Golunski, V. Astolfi, N. Carniel et al., "Ethanol precipitation and ultrafiltration of inulinases from kluyveromyces marxianus," Separation and Purification Technology, vol. 78, no. 3, pp. 261-265, 2011.

[22] D. J. Daroit, A. P. F. Correa, and A. Brandelli, "Production of keratinolytic proteases through bioconversion of feather meal by the Amazonian bacterium bacillus sp. P45," International Biodeterioration and Biodegradation, vol. 65, no. 1, pp. 45-51, 2011.

[23] O. H. Lowry, N. J. Rosebrough, A. L. Farr, and R. J. Randall, "Protein measurement with the folin phenol reagent," Journal of Biological Chemistry, vol. 193, pp. 265-275, 1951.

[24] D. M. Kanani and R. Ghosh, "A constant flux based mathematical model for predicting permeate flux decline in constant pressure protein ultrafiltration," Journal of Membrane Science, vol. 290, no. 1-2, pp. 207-215, 2007.
[25] Z. Li, A. H-Kittikun, and W. Youravong, "Purification of protease from pre-treated tuna spleen extract by ultrafiltration: an altered operational mode involving critical flux condition and diafiltration," Separation and Purification Technology, vol. 66, no. 2, pp. 368-374, 2009.

[26] D. J. Daroit, A. P. F. Correa, J. Segalin, and A. Brandelli, "Characterization of a keratinolytic protease produced by the feather-degrading Amazonian bacterium bacillus sp. P45," Biocatalysis and Biotransformation, vol. 28, no. 5-6, pp. 370-379, 2010.

[27] S. Radha and P. Gunasekaran, "Purification and characterization of keratinase from recombinant pichia and bacillus strains," Protein Expression and Purification, vol. 64, no. 1, pp. 24-31, 2009.

[28] J. D. Allpress, G. Mountain, and P. C. Gowland, "Production, purification and characterization of an extracellular keratinase from Lysobacter ncimb 9497," Letters in Applied Microbiology, vol. 34, no. 5, pp. 337-342, 2002.

[29] W. Suntornsuk, J. Tongjun, P. Onnim et al., "Purification and characterisation of keratinase from a thermotolerant featherdegrading bacterium," World Journal of Microbiology and Biotechnology, vol. 21, no. 6-7, pp. 1111-1117, 2005. 


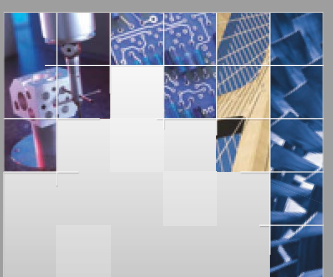

\section{Enfincering}
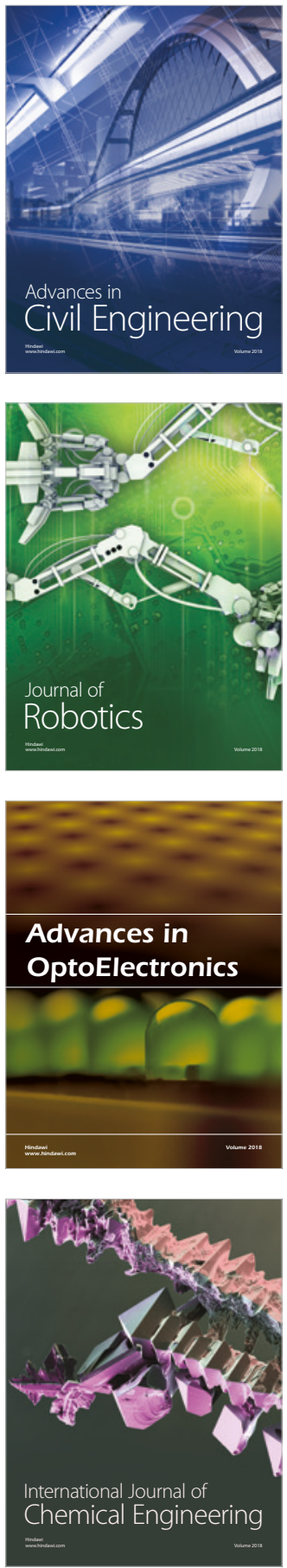

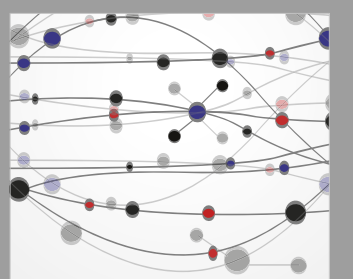

\section{Rotating \\ Machinery}

The Scientific World Journal

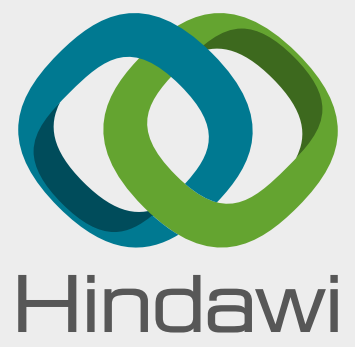

Submit your manuscripts at

www.hindawi.com
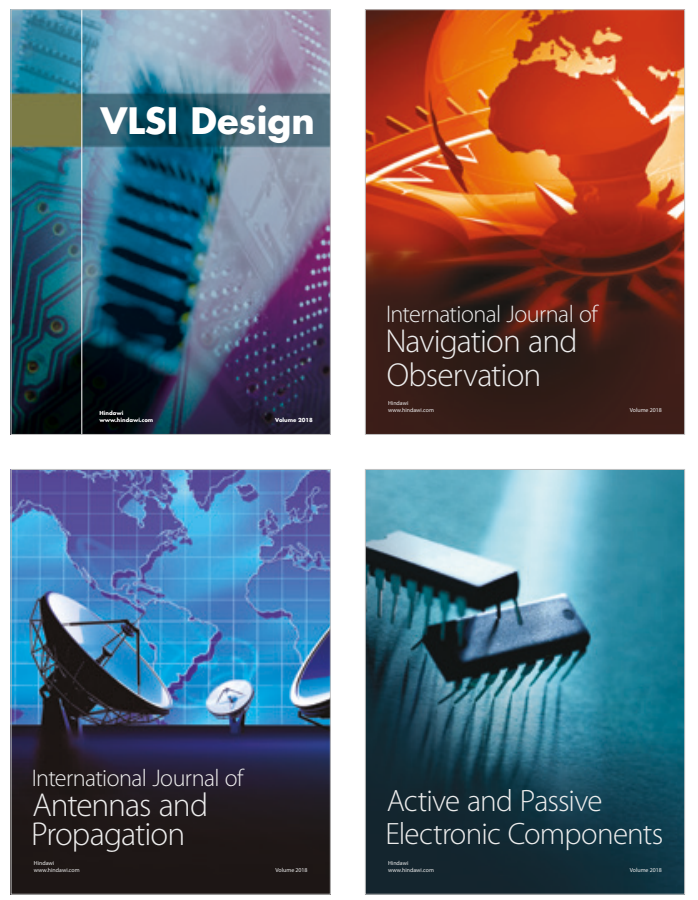
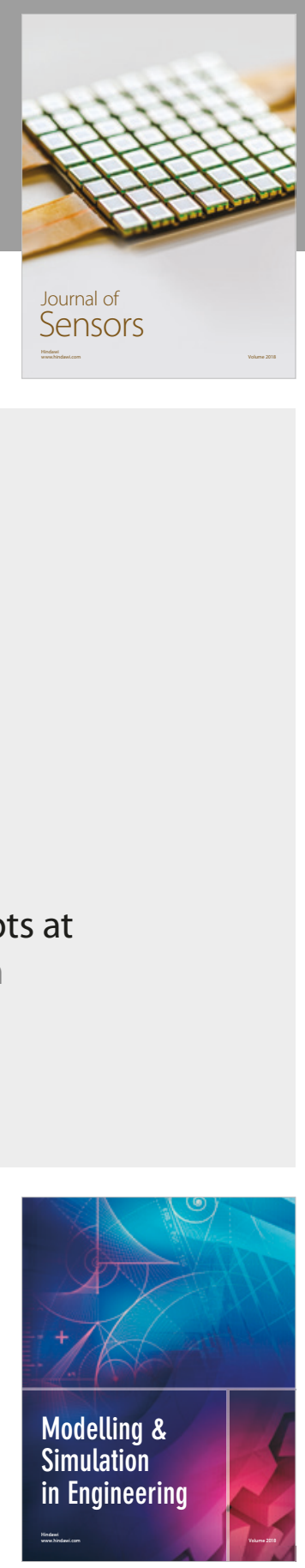

\section{Advances \\ Multimedia}
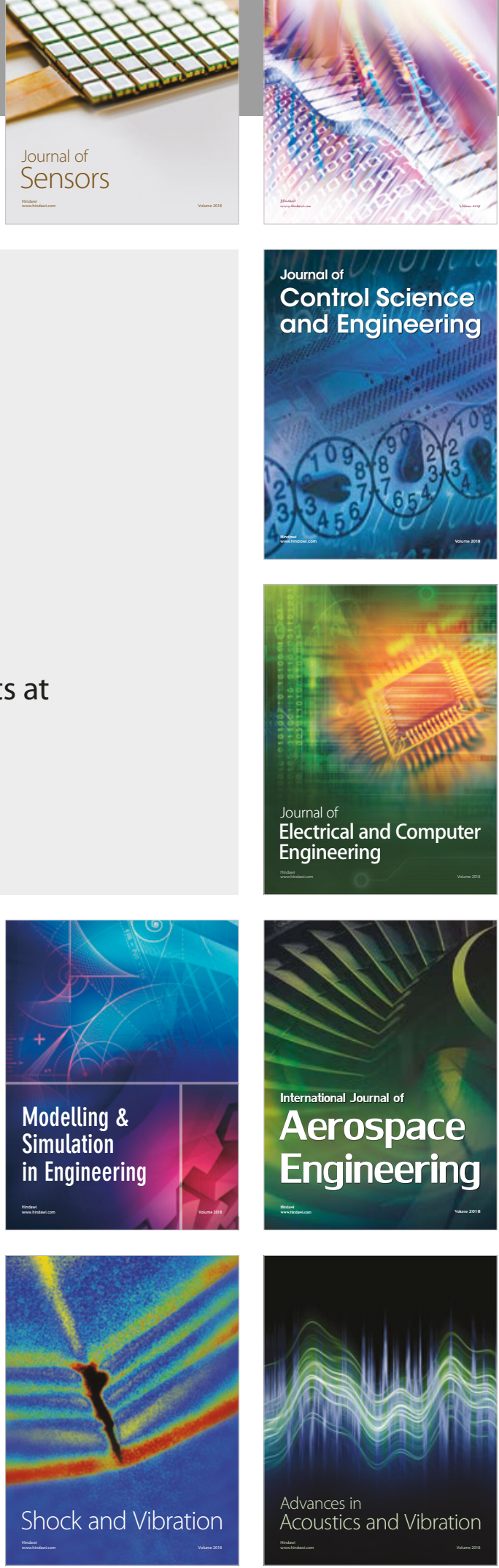